\title{
Bartosz Barański
}

Uniwersytet Warszawski

Wydziat Geografii i Studiów Regionalnych

Katedra Geografii Miast i Planowania Przestrzennego

e-mail: bbaranski@student.uw.edu.pl

\section{Dialog geografii humanistycznej z muzykologią: rozważania na temat Pałacu Kultury i Nauki w Warszawie na tle analogii muzycznych}

\begin{abstract}
Zarys treści: Artykuł prezentuje efekt „dialogu” geografii humanistycznej z muzykologią. Poprzez warszawskie studium przypadku przedstawiono autorskie podejście do nazywania i opisywania zjawisk występujących w przestrzeni miejskiej z wykorzystaniem muzycznych analogii. Pokazanie tego sposobu myślenia o mieście, czyli transpozycji zjawisk muzycznych na miejską przestrzeń wraz z wyjaśnieniem wybranych analogii między kompozycją muzyczną a urbanistyczną, jest głównym celem artykułu. Wybranymi do rozważań elementami konstrukcyjnie wspólnymi dla muzyki i urbanistyki są dominanta oraz tonika. W tekście pokazano, że centralność Pałacu Kultury i Nauki można przyrównać do muzykologicznej prawidłowości odniesienia dośrodkowego. Autorskie podejście przedstawiono także w krytycznym ujęciu, tzn. omówiono jego ograniczenia oraz podjęto próbę dyskusji nad jego uniwersalnością w różnych skalach przestrzennych.
\end{abstract}

Słowa kluczowe: muzyczne analogie, geografia humanistyczna, dominanta, tonika

\section{Wprowadzenie}

Miasto jest przedmiotem zainteresowania przedstawicieli wielu sfer życia oraz dyscyplin naukowych. Różnego rodzaju kwestiami z nim związanymi zajmują się zarówno jego główni kreatorzy, tzn. architekci, urbaniści, politycy i aktywiści, jak i zafascynowani jego specyfiką badacze, czyli m.in. socjologowie, ekonomiści czy etnolodzy. Wszyscy oni skupiają się zazwyczaj na innym aspekcie miejskości, a wynikiem tego są liczne opracowania teoretyczne i praktyczne, a także po prostu realne działania zmieniające przestrzeń miejską.

Istotną rolę w kształtowaniu wiedzy o mieście odgrywają geografowie, czyli reprezentanci dziedziny niejako integrującej różne aspekty miasta (społeczne, 
ekonomiczne, kulturowe, przyrodnicze itd.). Geograf najczęściej rozpatruje problematykę miejską przez pryzmat zjawisk przestrzennych, takich jak lokalizacja i rozmieszczenie obiektów, a także działalności człowieka w przestrzeni. W tego typu badaniach dominuje podejście scjentystyczne, typowe zresztą dla zdecydowanej większości badań.

W nauce dopuszcza się jednak też orientację antyscjentystyczną, która przyjmuje intuicyjny typ poznawania rzeczywistości i odrzuca obiektywizm nauk empirycznych (Chojnicki 1999). W geografii reprezentuje ją geografia humanistyczna, czyli wysoce wyspecjalizowana subdyscyplina pozwalająca na zrozumienie istoty różnego rodzaju zjawisk przestrzennych dzięki „podjęciu dialogu” ze współczesnymi naukami o człowieku (m.in. socjologią i etnologią) (Jędrzejczyk 2004). Miasto traktowane jest przez reprezentantów tego nurtu jako fenomen humanistyczny. Geografia humanistyczna rozpatruje więc miejską rzeczywistość jako coś wyjątkowego, a ponadto przybliża badaczy do dokonania pomiaru zjawisk o charakterze jakościowym.

Celem artykułu jest zaprezentowanie autorskiego podejścia do analizowania i opisywania przestrzeni miejskiej polegającego na transpozycji zjawisk muzycznych na przestrzeń miejską, czyli wskazaniu i wyjaśnieniu wybranych analogii występujących między kompozycją muzyczną a urbanistyczną. W tym przypadku geografia humanistyczna "podejmie dialog” z muzykologią. Przedstawiona zostanie interpretacja jednego fenomenu kulturowego (kompozycji miasta) poprzez drugi (muzykę). Ze wszystkich dziedzin sztuki muzykę wybrano ze względu na istnienie silnych związków między nią a architekturą i urbanistyką (Szmidt 1981, Satkiewicz-Parczewska 1993, Rasmussen 2015). Podobieństwa te umożliwiają posługiwanie się analogią, czyli kategorią dość rzadko stosowaną przez naukowców, a niekiedy w ogóle nieuznawaną za typ rozumowania naukowego.

Jednym ze wspólnych elementów kompozycji muzycznej oraz miejskiej pod względem konstrukcyjnym jest dominanta. Wyróżnia się zarówno dominantę architektoniczno-urbanistyczną (budynek lub inny obiekt), jak i muzyczną (akord). To na przykładzie tego elementu autor wyjaśnia zaproponowane podejście do analizowania i opisywania przestrzeni miejskiej z wykorzystaniem analogii muzycznych. Według zasad harmonii (działu teorii muzyki) akord dominantowy prowadzi do tzw. toniki, którą uznaje się za akord centralny kompozycji muzycznej. Tę muzykologiczną prawidłowość przeniesioną na przestrzeń autor ogólnie omówił w poprzednim artykule o charakterze koncepcyjno-teoretycznym (Barański 2018b). W tym opracowaniu pogłębione zostało studium przypadku Pałacu Kultury i Nauki (PKiN) wyznaczającego centrum kompozycji Warszawy, czyli hipotetycznie jej tonikę.

\section{Muzyczność architektury w świetle literatury przedmiotu}

Jeden z reprezentantów geografii humanistycznej, Jędrzejczyk (2004), uznawał podobieństwo krajobrazu miejskiego do muzyki za rzecz oczywistą. Nazywał go wręcz zastygłą muzyką. Stwierdzenie to jest nawiązaniem do poglądów 
niejednokrotnie głoszonych w dalszej i bliższej mu przeszłości przez przedstawicieli różnych dyscyplin nauki i sztuki. Choćby żyjący na przełomie XVIII i XIX w. filozof Fridrich von Schelling twierdził, że architektura to „zakrzepła muzyka”. Ustami jednej z bohaterek swoich powieści odwoływał się do tych słów nieco później również pisarz i poeta Johann Wolfgang von Goethe, uważający architekturę za muzykę ciągle brzmiącą w bezruchu, czyli niejako „skamieniałą muzykę” (Szmidt 1981). XX-wieczny filozof muzyki Roman Ingarden tłumaczył to zjawisko w bardzo uproszczony sposób, pisząc, że „może wydawać się to nieprawdopodobnym, żeby dzieło architektury nie było bardziej pokrewne dziełu malarskiemu lub rzeźbiarskiemu, a natomiast zbliżało się najwięcej - pod pewnym względem - do dzieła muzyki, ale tak się właśnie rzeczy mają" (Ingarden 2005, s. 132). Przyjmuje więc a priori, że kompozycja architektoniczna jest najbliższa kompozycji muzycznej pomimo oczywistych różnic wynikających z odmiennych materiałów decydujących o ich istnieniu.

Jak pisze Satkiewicz-Parczewska (1993), jedna z polskich badaczek analogii muzycznych w architekturze, architektura i muzyka są dziedzinami artystycznej działalności człowieka tylko z pozoru całkowicie odległymi od siebie. W jej opinii W rzeczywistości połączone są one silnymi powiązaniami szczególnego rodzaju. Podobieństwa między tymi dziedzinami sztuki zauważane są już od dawna przez architektów żyjących w różnych epokach historycznych. Choćby Witruwiusz, starożytny architekt rzymski, ze względu na zbieżność matematycznych prawideł konstrukcyjnych rządzących zarówno architekturą, jak i muzyką, uznawał znajomość zasad muzyki za obowiązek inżynierów (Szmidt 1981). Nawiązaniem do tego jest twórczość Ioannisa Xenakisa - XX-wiecznego twórcy będącego architektem i kompozytorem zarazem. Można domniemać, że silne związki między architekturą oraz muzyką wyczuwał i rozumiał więc lepiej niż ktokolwiek inny. W zakresie obydwu dyscyplin działał w oparciu o założenia matematyczne. Wzorem Witruwiusza korzystał $z$ matematycznych proporcji po to, aby kompozycja architektoniczna lub muzyczna były jeszcze doskonalsze.

Do wspomnianych wcześniej słów Schellinga i Goethego odwoływał się czołowy reprezentant architektonicznego modernizmu - Le Corbusier (XX w.), nazywając architekturę „zamrożoną muzyką". Ponadto podobnie jak Xenakis uznawał matematykę za spoiwo łączące muzykę z architekturą i słusznie twierdził, że „inżynier [...] ufający matematyce zestraja nas z prawami wszechświata. Osiąga harmonię [...]" (Le Corbusier2012, s. 59).

Muzykę za szczególnie inspirujący bodziec uznawał również Frank Lloyd Wright, jeden z najwybitniejszych architektów przełomu XIX i XX w. Poza Ludwigiem van Beethovenem niebywale cenił także Johanna Sebastiana Bacha. Uważał go za „wielki[ego] architekt[a], któremu zdarzyło się, że wybrał muzykę jako formę swojej twórczości" (za: Szmidt 1981, s. 392). Bachowskie kompozycje jako źródła inspiracji dla wielkich architektonicznych wizji wskazywał również żyjący mniej więcej w tym samym okresie architekt Erich Mendelsohn (Rasmussen 2015).

Poza architektami, literatami i filozofami związek architektury z muzyką zauważali - choć rzadziej - również muzycy. Jako przykład posłużyć może opinia 
skrzypka Samuela Duszkina, który w latach 40. XX w. pomagał kompozytorowi Igorowi Strawińskiemu w stworzeniu partii instrumentu solowego w „Koncercie in D" na skrzypce i orkiestrę. Wirtuoz obserwując umiejętności Strawińskiego podczas współpracy, stwierdził, że „postępował [on] jak architekt, który zmieniając układ pokoju na trzecim piętrze przerabia projekt aż do fundamentów dla zachowania proporcji całej budowli" (Jarzębska 2002, s. 178).

\section{Transpozycja dominanty i toniki z kompozycji muzycznej na kompozycję miejską}

Niewątpliwie podobieństwo architektury i muzyki pozwala na „przeniesienie” elementów kompozycji muzycznej na kompozycję architektoniczną (i odwrotnie). Tego typu transpozycja wcale nie jest nowością w świecie architektów, gdyż stosowana była w praktyce i pracy dydaktycznej przez wspomnianą Satkiewicz-Parczewską (2013).

Wesołowski (2006, s. 136), muzykolog, definiował transpozycję jako „przeniesienie melodii (utworu) do innej tonacji”. Na podobnej zasadzie opiera się metoda transpozycji Satkiewicz-Parczewskiej, tzn. na podstawie krzywej wrażeń słuchacza, będącej odzwierciedleniem m.in. rytmu i melodii danego utworu, ma miejsce urzeczywistnienie wizji wysłuchanej kompozycji muzycznej w postaci projektu trójwymiarowego modelu oraz na koniec - kompozycji architektonicznej. Jest to więc poniekąd przeniesienie substancji muzycznej na substancję architektoniczną.

Już samo wspólne pojęcie kompozycji w sposób szczególny dowodzi istnienia dużego podobieństwa między muzyką oraz architekturą. Autor niniejszego tekstu, omawiając kwestię analogii muzycznych w architekturze, wykracza jednak poza kompozycję pojedynczego budynku i skupia się na całej kompozycji miejskiej, czyli pewnego rodzaju układzie relacji między różnego rodzaju obiektami znajdującymi się w mieście. Według Wejcherta (1984, s. 15) „architektura jako sztuka twórcza przekształca się w urbanistykę, w architekturę przestrzeni”, czyli zespół architektoniczny współtworzący kompozycję urbanistyczną.

Pomimo ewidentnych różnic między kompozycją architektoniczno-urbanistyczną oraz muzyczną zidentyfikować można w nich pod pewnymi względami pokrewne elementy. Wynika to choćby z podobnej terminologii używanej w środowisku architektów i urbanistów oraz muzykologów i muzyków. Wśród tych elementów wyróżnić można m.in. rytmy, motywy, akcenty czy ornamenty (Wejchert 1984, Satkiewicz-Parczewska 1991, Rasmussen 2015). Jak wspomniano we wprowadzeniu, $w$ artykule tym jednym $z$ dwóch głównych przedmiotów rozważań jest jednak inny komponent terminologicznie wspólny dla architektury i urbanistyki oraz muzyki, czyli dominanta. Drugim elementem jest zaś tonika, która jako akord dotychczas funkcjonowała niemal wyłącznie w świecie muzyki (por. Barański 2018b). 
W muzyce „[f]unkcję dominanty spełnia akord, w którym wyczuwamy dążność do bezpośredniego przejścia (rozwiązania się) na tonikę" (Targosz 2011, s. 29), zaś „[f]unkcję toniki spełnia akord, słyszany jako ten, który może zakończyć utwór muzyczny lub jego fragment. Tonika jest więc funkcją, na której następuje rozwiązanie napięć harmonicznych" (Targosz 2011, s. 28), dając wrażenie zamknięcia kompozycyjnego. W harmonii klasycznej istotą dominanty jest konieczność rozwiązania (tzn. przejścia na inny akord) wynikająca z ciążeń i napięć, jakie powstają w tym dysonującym akordzie. Sedno toniki tkwi natomiast w jej centralności. A więc „[w] związku z tym, że dominanta dąży ku tonice, którą [...] uważa się za funkcję centralną, przejście dominanty na tonikę określamy jako tzw. odniesienie dośrodkowe" (Targosz 2011, s. 29).

Tymczasem $\mathrm{w}$ urbanistyce dominanta jest to obiekt skupiający $\mathrm{w}$ dużej mierze uwagę obserwatorów i odwracający ją od pozostałych składników krajobrazu miejskiego w tak znacznym stopniu, że inne komponenty wokół redukowane są niemal wyłącznie do roli tła. Poprzez swe gabaryty (czasem samą wysokość) bądź oryginalną bryłę forma taka potrafi zdominować pejzaż miasta oraz górować nad otaczającą zabudową. Ponadto - co jest najważniejsze w rozważaniach prowadzonych w tym artykule - dominanta może zaakcentować bądź wyznaczać lokalizację centrum miasta. Unaocznia to choćby przykład katedry w mieście Orvieto we Włoszech, o której Gyurkovich (1999, s. 5), architekt, pisał:

[B]o to, co najważniejsze w [...] mieście, ukryte jest w samym środku i ukazuje się nagle. [...] [S] toi (jeśli ten nieruchomy czasownik jest odpowiedni dla czegoś, co rozdziera przestrzeń i przyprawia o zawrót głowy) na obszernym placu, a otaczające kilkupiętrowe budynki po chwili gasną i przestaje się je dostrzegać.

Z powyższego przekazu wynika, że dominanta jest więc wspólnym pojęciem dla takich dyscyplin, jak urbanistyka oraz muzyka (choć oczywiście nie tylko tych). Według przewodniej idei autorskiego podejścia do analizowania i opisywania przestrzeni miejskiej dominantę muzyczną przyrównać można do dominanty architektoniczno-urbanistycznej. W artykule się przyjmuje, że w wyniku transpozycji elementów kompozycji muzycznej na miejską akord dominanty jest odpowiednikiem dominanty architektoniczno-urbanistycznej, czyli dzieła architektonicznego lub innego obiektu dominującego w krajobrazie miasta. Za tonikę kompozycji miejskiej można zaś uznać po prostu ścisłe centrum.

Bez wątpienia centrum odgrywa w mieście rolę pierwszoplanową, gdyż należy do jednych z najważniejszych kategorii przestrzennych (Jałowiecki 1986). To tam znajduje się pewnego rodzaju "punkt ciężkości miasta”, czyli najbardziej znane wśród użytkowników przestrzeni miejskiej miejsce wymiany wszelkich ludzkich aktywności (m.in. społecznych, kulturalnych i gospodarczych) znajdujące się zazwyczaj na zbiegu głównych szlaków komunikacyjnych.

O nierozerwalnym powiązaniu dominanty $\mathrm{z}$ tego typu obszarem $\mathrm{w}$ mieście Gyurkovich (1999, s. 56) pisał w następujący sposób: 
Pojawienie się dominanty oznaczało w tradycji, która ukształtowała się przez tysiąclecia historii rozwoju miast, istnienie związanej z nimi ważnej przestrzeni publicznej. To sprzężenie znaku z jego symboliką tkwiące gdzieś głęboko w podświadomości sprawia, że istnienie dominanty, której nie towarzyszy przestrzeń publiczna, odbierane jest jako dezinformacja.

Gyurkovich (2010, s. 31) uważa, że właściwie od zawsze „[d]ominanty sytuowane były w miejscach szczególnych w przestrzennej strukturze miasta. Będąc nośnikami istotnych informacji, wyznaczały położenie [...] miejskich placów o zróżnicowanym charakterze i funkcji”. Od czasów starożytnych po współczesne w miastach różnej wielkości wyznaczane przez dominantę miejskie centrum (tonika) przyjmowało więc postać zazwyczaj placu przed świątynią, zamkiem, pałacem, ratuszem (lub innymi siedzibami władz), charakterystyczną konstrukcją, dworcem, centrum handlowym czy nawet drapaczem chmur. Tonika miasta nie powinna być więc rozpatrywana wyłącznie jako matematycznie ustalony punkt centralny miasta, lecz zdecydowanie coś więcej - jako reprezentacyjne centrum o dużym znaczeniu społecznym, czyli wielofunkcyjna, ważna przestrzeń publiczna przyciągająca wielu użytkowników. Należy jednak zaznaczyć, że nie istnieje żadna wartość progowa, powyżej której daną przestrzeń można nazwać toniką. Zgodnie z postawą antyscjentystyczną przyjmuje się to intuicyjnie.

Miejsce centralne $\mathrm{w}$ mieście nazwane zostało toniką prawdopodobnie po raz pierwszy przez duńskiego architekta Steena Eilera Rasmussena. Według niego położone u podnóża prawie 260-metrowego wieżowca GE Builiding „Centrum Rockefellera [...] nadaje Nowemu Jorkowi tonikę, której inaczej byłoby mu brak" (Rasmussen 2015, s. 143). Przytoczony przez architekta przykład prezentuje w pewnym stopniu, jak w przestrzeni miejskiej dominanta układu przestrzennego wskazuje tonikę.

\section{Dominanta i tonika w kompozycji Warszawy - przykład Pałacu Kultury i Nauki}

Definiowane przez muzykologa Jacka Targosza muzyczne odniesienie dośrodkowe przeniesione na kompozycję miasta autor tego artykułu rozumie jako abstrakcyjne rozwiązanie dominanty na tonikę w przestrzeni miejskiej. Hipotetycznie ma ono miejsce np. w Warszawie. Nie ulega wątpliwości, że rolę dominanty architektoniczno-urbanistycznej pełni w niej Pałac Kultury i Nauki. Przez ponad 60 lat jego istnienia wielokrotnie powracano do pomysłów jego wyburzenia ze względu na przypisywaną mu symbolikę dawnego zniewolenia Polski przez ZSRR. Decydowano się jednak na mniej radykalne rozwiązanie, czyli neutralizację dominacji PKiN poprzez wznoszenie w jego pobliżu nowoczesnych wysokościowców. Pomimo tego na dominacyjny charakter PKiN względem pozostałej zabudowy nadal wpływają przede wszystkim jego gabaryty, a także forma architektoniczna i centralna lokalizacja (Barański 2018a). 
Jak pisał varsavianista Olgierd Budrewicz o okolicach PKiN, „wystarczy jedno spojrzenie na plan miasta, aby stwierdzić, że ten punkt wolno bezdyskusyjnie uznać za centrum stolicy Polski" (Budrewicz 2005, s. 56). Świadczy o tym nie tylko intensywnie zagospodarowana (poza placem Defilad) i użytkowana przestrzeń miejska o dużym znaczeniu w skali całego miasta, ale też rozwinięte funkcje usługowo-handlowe i odczuwalne nasycenie w treści kulturowe (Madurowicz 2008). Ponadto właśnie tam wykształcił się główny warszawski węzeł komunikacyjny, gdzie zarówno stacji metra, jak i przystankom autobusowym oraz tramwajowym nadano jednoznaczną nazwę „Centrum”.

Biorąc pod uwagę dotychczas prowadzone rozważania, można stwierdzić, że w kompozycji miejskiej Warszawy dominanta - tak jak w utworze - wyznacza tonikę. Ale czy to, co bezpośrednio otacza Pałac, jest miejscem miłym dla oka, tak jak tonika w dziele muzycznym jest akordem przyjemnym dla ucha? Przedstawione zaraz argumenty świadczyć będą o ograniczeniach proponowanego przez autora podejścia do analizowania i opisywania przestrzeni miejskiej.

Lew Rudniew, główny projektant PKiN, już podczas wznoszenia obiektu snuł arkadyjskie wizje dotyczące funkcjonowania okolic tego obiektu. W imieniu wszystkich twórców mówił: „chcielibyśmy, ażeby miejsce to stało się ulubionym miejscem warszawiaków, takim, jakim są obecnie Łazienki, ażeby warszawiacy tutaj przychodzili, spacerowali, odpoczywali, by tu bawiły się dzieci i tryskały fontanny" (za: Chomątowska 2005, s. 244). Od dawna pojawiają się jednak opinie, że najbliższe sąsiedztwo Pałacu, czyli tzw. kwartał centralny (wyznaczony przebiegiem ulic Marszałkowskiej, Świętokrzyskiej, Emilii Plater i Al. Jerozolimskich), zwłaszcza od strony głównego wejścia do Pałacu, funkcjonuje w pewnym sensie jako „betonowa pustynia”, „wyrwa w tkance miasta” czy „dziura urbanistyczna”, nieprzystająca zresztą do tak okazałego dzieła architektonicznego, jakim jest PKiN.

Zlokalizowany od strony głównego wejścia do budynku plac Defilad pozbawiony pierzei aż z trzech stron (nie spełniając tym kryteriów klasycznego placu) i służący od lat 60. aż do dzisiaj jako parking dla samochodów i autobusów (a niegdyś także jako miejsce bazarowego handlu i lunaparkowej rozrywki) nie tworzy więc pełnowartościowej centralnej przestrzeni publicznej. Giergij Karawajew, radziecki pełnomocnik ds. budowy PKiN, który po ukończeniu inwestycji żegnał się z polską stolicą, rzekł: „[d]o widzenia, Warszawo, tu zostawiłem kawałek serca” (Chomątowska 2015, s. 74). Po wielu latach, obserwując prowizorycznie urządzone targowisko i parking u stóp Pałacu podczas wycieczki na taras widokowy, nie mógł uwierzyć, że tak ponadprzeciętne dzieło architektury spotyka tego typu upokorzenie. Ponadto ze względu na skutki wprowadzenia w latach 40. tzw. dekretu Bieruta (który przez wywłaszczenie gruntów z rąk prywatnych właścicieli miał ułatwić odbudowę Warszawy), plac Defilad wydaje się miejscem straconym dla kreowania jakichkolwiek idei centrum nowoczesnej metropolii.

W 2006 roku zapadła decyzja o likwidacji elementów substandardowego zagospodarowania przestrzennego kwartału centralnego tworzących wielki bazar. Wtedy uchwalono również pierwszą wersję miejscowego planu zagospodarowania przestrzennego (wielokrotnie później zmienianego), który zakładał utworzenie w obrębie placu Defilad m.in. Muzeum Sztuki Nowoczesnej oraz TR 
Warszawa. Niestety realizację tych, a także wielu innych pomysłów na stworzenie wzorcowej centralnej przestrzeni publicznej w otoczeniu PKiN do dzisiaj utrudniają skutki wspomnianej nacjonalizacji gruntów sprzed lat.

Bazar zlikwidowano, ale funkcja parkingowa pozostała. Oznacza to, że przestrzeń to ma swoich użytkowników, w dodatku dość licznych. Jednak czy właśnie tylko kierowców i osób oczekujących na autokary należy spodziewać się w miejscu, które wraz z historyczną częścią Warszawy powinno funkcjonować jako jej najbardziej reprezentacyjna przestrzeń?

W porównaniu do placu Defilad znacznie lepiej prezentują się północna i południowa część kwartału centralnego. Na północy znajduje się tzw. park Świętokrzyski, gdzie wśród drzew, fontann i pomników różni użytkownicy centrum mają szansę na odnalezienie chwili spokoju nawet tuż obok sąsiadujących z nim najbardziej ruchliwych ulic Warszawy. Od strony południowej również zlokalizowane są elementy miejskiej zieleni, a ponadto miejsce to słusznie funkcjonuje jako jeden $z$ ważniejszych $\mathrm{w}$ Warszawie i najczęściej uczęszczanych przez ludzi ciągów pieszych łączących ważne pod względem komunikacyjnym miejsca - stację metra Centrum z Dworcem Centralnym (i sąsiadującą z nim galerię handlową Złote Tarasy). Skoro znajduje się tam zieleń i (poza niemal bezpośrednio przylegającymi do Pałacu jezdniami) panuje głównie ruch pieszy, to poniekąd wpisują się te kwestie w cechy wartościowej przestrzeni publicznej. Ostatnia, zachodnia i najwęższa część kwartału centralnego funkcjonuje głównie jako teren wjazdu na dziedziniec PKiN i ewentualnie chodnik z przystankami transportu publicznego.

W zmienionym w 2010 r. wspomnianym planie miejscowym dotyczącym okolic Pałacu wyraźnie zaznaczono, że zdecydowano się na „pozostawienie w niezmienionej formie, wpisanego do rejestru zabytków, budynku PKiN oraz zachowanie jego dotychczasowej funkcji centrotwórczej [...]" (Uchwała nr XCIV/2749/2010 Rady Miasta Stołecznego Warszawy z dnia 9 listopada 2010 r. w sprawie miejscowego planu zagospodarowania przestrzennego w rejonie Pałacu Kultury i Nauki w Warszawie, s. 6). Nie ulega więc wątpliwości, że to właśnie Pałac wyznacza warszawskie centrum, jednak problem tkwi w jakości tej przestrzeni, zwłaszcza w obrębie placu Defilad. Dotychczas zamiast funkcjonować jako reprezentacyjna wizytówka stolicy, przynosi jej mieszkańcom wstyd. Według wyników badania opinii mieszkańców pn. Barometr Warszawski z listopada 2015 r. $^{1}$ rewitalizacja tego placu jest jedną z najpilniejszych inwestycji. Zdaniem respondentów pod względem wagi wyprzedzają ją jedynie budowa obwodnicy Warszawy, budowa/ dokończenie II linii metra oraz budowa mieszkań komunalnych. W zależności od pory roku na placu Defilad pojawiają się co prawda różnego rodzaju elementy tymczasowego zagospodarowania, np. lodowisko, boisko do siatkówki, lokale gastronomiczne, a nawet przejawy sztuki ulicznej (co oczywiście poniekąd spotyka się z zainteresowaniem mieszkańców i turystów), ale „serce Warszawy” zdecydowanie zasługuje na coś więcej - na stałe zagospodarowanie czyniące $z$ bezpośrednich okolic dominanty w postaci PKiN prawdziwe centrum Warszawy, czyli tonikę w jej kompozycji.

http://www.um.warszawa.pl/o-warszawie/warszawa-w-liczbach/2015 (dostęp: 6.06.2019). 
Jak wynika z komunikatów Biura Architektury i Planowania Przestrzennego Urzędu m.st. Warszawy z końca 2018 r., plac Defilad ma zmienić nazwę na plac Centralny ${ }^{2}$. To jeszcze mocniej potwierdzałoby istnienie w kompozycji Warszawy muzykologicznej prawidłowości rozwiązania dominanty na tonikę, której najważniejszym przymiotem jest centralność. Oczywiście zmiany nie kończą się na korekcie samej nazwy. Zwycięska koncepcja architektoniczno-urbanistyczna zakłada utworzenie na tym placu dwóch dodatkowych pierzei w postaci gmachów wspomnianych Muzeum Sztuki Nowoczesnej i TR Warszawa. Oprócz tego zwiększyć ma się ilość zieleni (m.in. zagajnik płytko zasadzonych drzew szkółkowych, klomby kwiatów), a także liczba miejsc do siedzenia. Zmianie ma też ulec posadzka. Nowe ułożenie granitowej kostki (tej obecnej, ale wyczyszczonej) ma odzwierciedlać układ uliczek nieistniejącego już centrum stolicy z XIX w.

Na razie jednak ambitne plany utworzenia wokół PKiN pełnowartościowej przestrzeni publicznej są w fazie koncepcyjnej. Dominanta warszawska, choć wyznacza centrum, w świetle przyjętej przez autora definicji na razie nie wyznacza jednak toniki kompozycji Warszawy. Tu wychodzi na jaw ograniczenie zaproponowanego podejścia do analizowania i opisywania przestrzeni miejskiej z użyciem muzycznych analogii polegającego na transpozycji dominanty i toniki na kompozycję architektoniczno-urbanistyczną. W przypadku Warszawy zastosowanie jej okazuje się jeszcze nie do końca trafione, aczkolwiek po realizacji zakładanych zmian na placu Defilad w Warszawie być może w przyszłości „wybrzmi” poprzedzona dominantą tonika.

Autor przestudiował też kwestię uniwersalności podejścia w przypadku miejskich jednostek różnej wielkości i rangi. Przywołując wcześniej optykę architekta Jacka Gyurkovicha, wskazano, że od wieków bez względu na uwarunkowania kulturowe i tradycje urbanistyczne w różnych zakątkach świata miejskie centra przyjmują często postać placu zlokalizowanego przed np. świątynią, zamkiem, pałacem, ratuszem (lub innymi siedzibami władz), charakterystyczną konstrukcją, dworcem, centrum handlowym czy drapaczem chmur. Taką właściwość zidentyfikować można $\mathrm{w}$ wielu miastach, a także ich dzielnicach.

W przypadku miast różnej wielkości, w których krajobrazie możliwa jest identyfikacja dominanty, najczęstsza jest dominacja obiektu sakralnego (np. kościoła, synagogi, meczetu itd.). Przy nim bardzo często znajduje się centralna przestrzeń o dużym znaczeniu społecznym przyciągająca $w$ ciągu doby licznych użytkowników - zarówno mieszkańców, jak i turystów. Jako przykłady posłużyć mogą przede wszystkim miasta małe lub średniej wielkości, np. Ulm, Fryburg Brezgowijski, Szlezwik (Niemcy), a także miasta duże, m.in. Barcelona i Sewilla (Hiszpania), Helsinki (Finlandia), Tallin (Estonia), Antwerpia (Belgia), Florencja (Włochy), Rejkiawik (Islandia), Kolonia (Niemcy), Toruń, Częstochowa i Gdańsk (Polska). To właśnie w pobliżu dominujących w krajobrazie katedr lokalizuje się historyczne centrum, „serce miasta” o bardzo istotnej funkcji społecznej, czyli tonika kompozycji miejskiej. Poza kościołami wyraźnymi dominantami wielu małych miast w Polsce są ratusze, będące siedzibami władz miejskich. Klasycznymi

2 http://architektura.um.warszawa.pl/wyborplaccentralny (dostęp: 10.06.2019). 
przykładami w tym przypadku są np. Zamość, Kalisz i Pułtusk. W miastach tych ratusze wyraźnie wyznaczają najważniejsze miejsce centralne, czyli rynek pełniący funkcję toniki w kompozycji urbanistycznej. Specyficznym przykładem dominanty ewidentnie wyznaczającej tonikę miasta jest także cały zespół zabudowy na Wawelu w Krakowie.

W rozważaniach na temat dominanty wskazującej tonikę w kompozycji miejskiej kontrprzykładem mogą być natomiast wieżowce (np. biurowce czy apartamentowce). Niekiedy bywają to budynki niejako aspirujące do miana dominanty, jednak rzadko kiedy wokół nich kształtowana jest wzorcowa przestrzeń publiczna służąca szerszej społeczności. Zagospodarowanie przestrzenne zwykle ograniczone jest do niezbędnego minimum pod kątem potrzeb użytkowników pracujących lub mieszkających w danym drapaczu chmur. Wieżowce, choć często bywają dominantami wysokościowymi (niekiedy nawet w skali całego miasta, np. w Gdyni czy we Wrocławiu), z reguły nie wyznaczają toniki w kompozycji miejskiej. Niestety w Warszawie najwyższy drapacz chmur, w dodatku o tak dużym znaczeniu historycznym, również toniki jeszcze nie wyznacza.

Rozwiązanie dominanty na tonikę $\mathrm{w}$ przestrzeni zidentyfikować można także w jeszcze mniejszej skali niż miasto. Zdarza się, że poszczególne fragmenty miasta (np. dzielnice) mają swoje lokalne dominanty urbanistyczne, wyznaczające lokalne centrum. Tutaj jako przykład posłużyć może choćby strzelisty kościół pw. Stanisława Kostki na warszawskim Żoliborzu, który zlokalizowany jest tuż obok placu Wilsona. Zdaniem autora bez wątpienia jest to plac o największym znaczeniu dla żoliborskiej społeczności. Oznacza to, że podejście zaproponowane do omawiania zjawisk występujących w przestrzeni miejskiej z wykorzystaniem muzycznych analogii można zastosować do miejskich jednostek różnej wielkości.

\section{Podsumowanie}

Zaprezentowane $\mathrm{w}$ artykule rozważania varsavianistyczne wpisują się $\mathrm{w}$ zakres geografii humanistycznej podejmującej „dialog” z muzykologią. W tekście przedstawiono interpretację jednego fenomenu kulturowego (kompozycji miasta) poprzez drugi (kompozycji muzycznej). Zastosowanie struktur artystycznych do analizy miejskiej rzeczywistości przede wszystkim wzbogaciło instrumentarium narzędzi opisu przestrzeni miejskiej, zwłaszcza warszawskiej.

Mimo że harmoniczne odniesienie dośrodkowe funkcjonowało dotychczas jedynie w sferze kompozycji muzycznych, okazuje się ono zjawiskiem występującym niejako również w kompozycji urbanistycznej. Przedstawione w artykule argumenty potwierdzają tezę głoszącą, że w kompozycji miejskiej Warszawy znajduje się miejsce centralne wyznaczone przez dominantę architektoniczno-urbanistyczną w postaci Pałacu Kultury i Nauki. Warszawskiego centrum, mimo jego ogromnego znaczenia społecznego zarówno w skali lokalnej, jak i krajowej, ze względu na jakość przestrzeni wokół Pałacu nie można jednak jeszcze uznać za tonikę w kompozycji miejskiej. Na tym polega ograniczenie zaproponowanego podejścia do analizowania i opisywania przestrzeni miejskiej z wykorzystaniem 
muzycznych analogii, że nie każde zidentyfikowane centrum wyznaczane przez dominantę można nazwać toniką.

Jak pokazują przytoczone w artykule przykłady różnych miejskich jednostek, przedstawione podejście ma charakter dość uniwersalny. Wyobrażone rozwiązanie dominanty na tonikę zidentyfikować można zarówno w skali całego miasta (bez względu na jego wielkość), jak i w układzie bardziej lokalnym (np. dzielnicowym).

\section{Literatura}

Barański B. 2018a. Widoczność Pałacu Kultury i Nauki w kompozycji urbanistycznej Warszawy (perspektywa przechodnia). Prace i Studia Geograficzne, 63, 4: 53-68.

Barański B. 2018b. Dominanta i tonika w kompozycji miasta. Przestrzenne rozważania na tle analogii muzycznych. Polski Rocznik Muzykologiczny, 16: 116-130.

Budrewicz B. 2005. Wieżowiec zwany Pałacem. Renowacje i Zabytki, 3: 55-60.

Chojnicki Z. 1999. Podstawy metodologiczne i teoretyczne geografii. Bogucki Wydawnictwo Naukowe, Poznań.

Chomątowska B. 2015. Pałac. Biografia intymna. Znak, Kraków.

Gyurkovich J. 1999. Znaczenie form charakterystycznych dla kształtowania i percepcji przestrzeni. Wybrane zagadnienia. Politechnika Krakowska im. Tadeusza Kościuszki, Kraków.

Gyurkovich J. 2010. Architektura w przestrzeni miasta. Wybrane problemy. Wydawnictwo Politechniki Krakowskiej, Kraków.

Ingarden R. 2005. Wybór pism estetycznych. Kraków.

Jałowiecki B. 1986. Społeczne funkcje i znaczenie centrum miasta. [W:] Centrum miasta - centrum Wrocławia. Materiały konferencji naukowej zorganizowanej w dniach 5-7 grudnia $1984 \mathrm{r}$. we Wrocławiu. Zakład Narodowy im. Ossolińskich, Wrocław, Warszawa, Kraków, Gdańsk, Łódź, s. $171-176$.

Jarzębska A. 2002. Strawiński. Myśli i muzyka. Kraków.

Jędrzejczyk D. 2004. Geografia humanistyczna miasta. Dialog, Warszawa.

Le Corbusier. 2012. W stronę architektury. Warszawa.

Madurowicz M. 2008. Miejska przestrzeń tożsamości Warszawy. Wydawnictwo Uniwersytetu Warszawskiego, Warszawa.

Rasmussen S.E. 2015. Odczuwanie architektury. Karakter, Kraków.

Satkiewicz-Parczewska A. 1993. Rytm w architekturze jako główny element kompozycji na tle analogii z muzyką. Wydawnictwo Uczelniane Politechniki Szczecińskiej, Szczecin.

Satkiewicz-Parczewska A. 2013. Autorska metoda transpozycji muzyki na architekturę. Przestrzeń i Forma, 20: 95-110.

Szmidt B. 1981. Ład przestrzeni. Państwowy Instytut Wydawniczy, Warszawa.

Targosz J. 2011. Podstawy harmonii funkcyjnej. Polskie Wydawnictwo Muzyczne, Kraków.

Wesołowski F. 2006. Zasady muzyki. Polskie Wydawnictwo Muzyczne, Kraków.

Wejchert K. 1984. Elementy kompozycji urbanistycznej. Arkady, Warszawa.

\section{Akt prawny}

Uchwała nr XCIV/2749/2010 Rady Miasta Stołecznego Warszawy z dnia 9 listopada 2010 r. w sprawie miejscowego planu zagospodarowania przestrzennego w rejonie Pałacu Kultury i Nauki w Warszawie. 


\title{
The dialogue of human geography with musicology: reflections on the Palace of Culture and Science in Warsaw in the context of musical analogies
}

\begin{abstract}
The article is the effect of "dialogue" of human geography and musicology. It presents the author's approach of analysis and description of urban space with the using of musical analogies through the Warsaw case study. The main goal of this article is to present this approach, which is transposition of musical phenomena into the urban space, and to explain selected analogies between the musical and urban composition. The elements chosen for consideration are dominant and tonic. They are constructively common to music and urban planning. In this article the author presented that the centrality of the Palace of Culture and Science can be compared to the musicological regularity of the centripetal reference. The author presented also the approach's deficiency and discussed its universality in various spatial scales.
\end{abstract}

Key words: musical analogies, human geography, dominant, tonic 